\title{
A Case Study of Educational Management Readiness in Educating People
}

\author{
Tanat Titiworatat \& Vichian Puncreobutr \\ St.Theresa International College, Thailand
}

\begin{abstract}
This research was aimed at studying the readiness level of educational management in providing education in the Thai-Lao border region of Bung Karn Province. The study compared the readiness level of educational management in terms of nationality and category of respondents. The target respondents of the study are parents, students and teachers/administrators who live along Thai-Lao border of Bung Karn Province. The estimated sample size of the study was 384 based on Krejcie and Morgan Table. The survey questionnaire was constructed for the study and tested for reliability, which hold good reliability with Cronbach alpha value at .82. Statistical tools used for the study are Mean, T-Test and One-way ANOVA. The result indicated that major group of respondents are Laos people and most of them are willing to work in Thailand and foreign nations. The overall readiness of educational management is at moderate level, whereas the aspects like academics and resources are highly ready to serve the people in the region. But in terms of international program, the educational management is not yet ready to serve the community. When comparing the readiness of educational management in terms of nationality, there is no significant difference among Thais and Laos People, but in terms of category of respondents (Parents, Students and Teachers) significant difference exists. Further pair wise comparison test has been conducted and it is found that the significant difference exists in parents' group towards readiness of educational management.
\end{abstract}

Keywords: readiness; educational management; Bueng Kan Province.

\section{Introduction}

Bueng Kan, the $77^{\text {th }}$ province of Thailand borders with neighboring Lao People's Democratic Republic and covers a distance of $330 \mathrm{kms}$. The mighty Mekong River, also known as a border river separates both the countries in this area. There is one permanent border crossing checkpoint in Thailand and it also serves as the permanent customs office between Bueng Kan province of Thailand and Pakxan City, Bolikhamxai province of Lao People's Democratic Republic (Bureau of International Relations, 2008). The province flourishes with a gross domestic product (GPP: Gross Provincial Product) of more than 20,00o million baht, and with a border trade worth more than 4,300 million baht. The people of two countries have trade contacts or business deals which are increasing in numbers every year (Office of the Commission on Basic Education, Ministry of Education, 2007).In addition, the opening up of Free Trade under the General Agreement on Trade in Services (GATS) has determined that trade, services and education services, are also branches of the trade liberalization and negotiations. In addition, the free trade opening with educational services will not only create benefits to educational development, but also will be 
conducive to the growth of trade and economy of the country (Suwannee Khammun, 2002), as well as, following up the revised National Education Plan (2009-2016), it has also established guidelines for the development and promotion of international cooperation. Education development, as well as the development of internationalization of education is to support and recognize the ASEAN Community (AEC) (Sermsakdi Visalaporn, 20o9) and it increases the potentials of competitiveness of both the countries. With the implementation framework, there are 7 dimensions and the $7^{\text {th }}$ dimension has set for the promotion of educational institutes and organize/ manage the international programs, introducing new courses or jointly offering courses with other foreign institutions; to present the internationalization of education and to cope with international labor markets (Bureau of International Relations, 2010).

Since it is end of the action plan- National Education Plan (20o9-2016), the researcher suggests that there should be a study on the readiness of educational management to educate Lao people along the Thai- Lao borders, Bueng Kan province. Since for the purpose of assessing the implementation works of the National Education Plan and then offering recommendations for preparing the next national education plan.

\section{Objectives of the Research}

1. To study the readiness level of educational management in educating the Lao public people along Thai-Lao borders at Bueng Kan Province.

2. To find out the significant difference among the respondents based on nationality and category (Students, Parents and Teachers) towards the readiness of educational management.

\section{Research Methodology}

The target population of the study is approximately around 100,000, including students' parents, teachers and students, who live along the Thai-Lao border of Bueng Kan province. The sampling method adopted for the study is simple random sampling and the estimated sample size is 384 based on the Krejcie and Morgan table. Research variables include both nationality and category of the respondents; meanwhile the dependent variable is the readiness of educational institutions. The survey instrument was constructed by the researcher and tested for reliability. The discrimination ranges from .45-.86 and the Cronbach alpha value is .82 , which holds high reliability. The statistical tests used for the study is Mean, T-Test and One-Way ANOVA.

\section{Data Analysis and Discussion}

\section{Descriptive profile of the respondents}

In this study, the sample respondents of the study is composed of Thais and Lao people and it is found that 25.8 percent are Thais and 74.2 percent are Lao people. Following with the respondents' category, 40.6 percent are student, parents and concerned people, 33.6 percent are students and 25.8 percent are teachers and school administrators. With regard to the class/year of the students, the major group of respondents is in secondary school level (Primary Mathayomsueksa) at 57.3 percent, high school level (High Mathayomsueksa) at16.9 percent and others contributed for $\mathbf{2 5 . 8}$ percent. Further the classification made based on the purpose of 
study and reported that 61.2 percent of the respondents are willing to work in Thailand, 5.5 percent willing to work in Laos and 33.3 percent are willing to work in other countries.

\section{Readiness levels of educational management}

The readiness levels of educational management at Bueng Kan Province is shown in the Table 1-3

Table.No.1 shows the overall readiness of educational management with regard to academics, natural resources and international programs $(\mathrm{N}=384)$.

\begin{tabular}{|l|c|c|c|}
\hline \multicolumn{1}{|c|}{ Items } & Means & \multicolumn{1}{c|}{ S.D. } & Levels of readiness \\
\hline Readiness of academics & 4.4443 & .48088 & High \\
\hline Readiness of natural resources & 4.5755 & .62750 & Very High \\
\hline Readiness of international programs & 1.5840 & .55266 & Low \\
\hline $\begin{array}{l}\text { Readiness of educational management as } \\
\text { overall }\end{array}$ & 3.6046 & .28252 & Moderate \\
\hline
\end{tabular}

From the Table 1 , it is found that, the overall readiness of educational management to provide education at Bueng Kan province is at moderate level (3. 6046 by average). While considering all items, it is found that the score for readiness of resources is very high. The readiness of academics is at high level, whereas the readiness of international programs is at low level.

Table.No.2 shows the readiness level of educational management in academics $\left(\mathrm{N}=\mathbf{3 8 4}^{8}\right)$

\begin{tabular}{|l|r|r|c|}
\hline \multicolumn{1}{|c|}{ Items } & \multicolumn{1}{c|}{ Means } & \multicolumn{1}{c|}{ S.D. } & Level of readiness \\
\hline $\begin{array}{l}\text { Curriculum management and Course } \\
\text { planning }\end{array}$ & 4.7630 & .44964 & Very High \\
\hline Student Admission & 4.5573 & .56610 & Very High \\
\hline Arrange the class & 4.3333 & .61600 & High \\
\hline Learning methods & 4.3490 & .68790 & High \\
\hline Learning outcomes assessment & 4.2188 & .71102 & High \\
\hline Readiness of academics & 4.4443 & .48088 & High \\
\hline
\end{tabular}

From the table 2, it is found that the overall readiness level of educational management in handling academic studies is at high level. For the items program or curriculum management/course planning, and student admission the scores are very high. Whereas readiness level for the items, learning methods, arranging classes, and the assessment of learning outcomes, scores high respectively.

Table.No.3 shows the readiness level of educational management on resources $(\mathrm{N}=384)$.

\begin{tabular}{|l|c|c|c|}
\hline \multicolumn{1}{|c|}{ Items } & mean & S.D. & Level of readiness \\
\hline Teacher manpower & 4.6901 & .67812 & Very High \\
\hline Budget for organizing learning activities & 4.6484 & .69601 & Very High \\
\hline Teaching tools and equipment & 4.5339 & .72544 & Very High \\
\hline Management & 4.4297 & .69331 & Very High \\
\hline Readiness of resources & 4.5755 & .62750 & Very High \\
\hline
\end{tabular}

From the table 3, it is inferred that the overall readiness level of educational management on resources is very high. For the individual items; manpower of teachers, budget for organizing learning activities, teaching tools \& equipment and management; the readiness level is very high.

Table.No.4 shows the readiness level of educational management on the international program $(\mathrm{N}=384)$. 


\begin{tabular}{|l|c|c|c|}
\hline \multicolumn{1}{|c|}{ Items } & means & \multicolumn{1}{c|}{ S.D. } & Level of readiness \\
\hline International program management & 1.4427 & .60619 & Very Low \\
\hline $\begin{array}{l}\text { The course curriculum or programs } \\
\text { organized along with foreign institutions }\end{array}$ & 1.6276 & .62945 & Low \\
\hline State of internationalization of education & 1.6250 & .70803 & Low \\
\hline International labor market support & 1.6406 & .67867 & Low \\
\hline Readiness of international programs & 1.5840 & .55266 & Low \\
\hline
\end{tabular}

From the table 4, it is examined that the overall readiness level of educational management towards International Program scores low. For the individual items, the course curriculum or programs organized in collaboration with foreign institutions, state of the internationalization of education, and support for the international labor market also scores low, whereas the item international program management scores very low. Hence the overall readiness level related to international program is at low level.

Table.No.5 Comparison of the readiness level of educational management based on nationality of the respondents

\begin{tabular}{|l|r|r|r|r|r|r|}
\hline \multirow{2}{*}{ Readiness Categories } & \multicolumn{2}{|c|}{ Thai(N=99) } & \multicolumn{2}{c|}{ Lao PDR (N=285) } & \multirow{2}{*}{ t } & \multirow{2}{*}{ P } \\
\cline { 2 - 5 } & \multicolumn{1}{c|}{ Mean } & \multicolumn{1}{c|}{ S.D. } & \multicolumn{1}{c|}{ Mean } & \multicolumn{1}{c|}{ S.D. } & & \\
\hline Academics & 4.3980 & .45130 & 4.4604 & .49048 & -1.112 & .267 \\
\hline Resources & 4.5152 & .64663 & 4.5965 & .62050 & -1.111 & .267 \\
\hline International Programs & 1.6439 & .60934 & 1.5632 & .53112 & 1.254 & .211 \\
\hline
\end{tabular}

${ }^{*} \mathrm{p}<.05{ }^{* *} \mathrm{p}<.01$

From the table 5, it is examined that there is no significant difference exists among nationality of the respondents towards the readiness categories of educational management. The p-value is greater than $.05 \&$.01 respectively.

Table.No.6 Comparison of the readiness level of educational management based on respondents' category

\begin{tabular}{l|l|r|r|r|r|c}
\hline Readiness/ Availability & Source & \multicolumn{1}{c|}{ SS. } & \multicolumn{1}{c|}{ df. } & \multicolumn{1}{l|}{ MS. } & \multicolumn{1}{c|}{ F } & P \\
\hline Academics & Between Groups & 11.209 & 2 & 5.605 & $27.604^{* *}$ & .000 \\
& Within Groups & 77.358 & 381 & .203 & \\
\cline { 2 - 7 } & Total & 88.567 & 383 & & & \\
\hline Resources & Between Groups & 3.333 & 2 & 1.666 & $4.305^{*}$ & .014 \\
& Within Groups & 147.477 & 381 & .387 & & \\
\cline { 2 - 7 } & Total & 150.810 & 383 & & & \\
\hline International Programs & Between Groups & 3.762 & 2 & 1.881 & $6.330^{* *}$ & .002 \\
& Within Groups & 113.217 & 381 & .297 & & \\
\cline { 2 - 7 } & Total & 116.979 & 383 & & & \\
\hline
\end{tabular}

${ }^{*} \mathrm{p}<.05 \quad{ }^{* *} \mathrm{p}<.01$

From the Table 6,it is observed that there is a significant difference exists among different category of respondents. The p-value is statistically significant at 0.01 level for academics and international programs, whereas for resources p-value is significant at 0.05 level. Hence there is a significant difference exists among students' parents, students and teachers/administrators towards readiness of educational management. It concludes there is a significant difference, but it doesn't refer where the differences lies. To isolate the differences, it needs further testing on pairs. 
Table.No.7 Testing the differences of pairs (parents, students, teachers/administrators) towards readiness of educational management.

\begin{tabular}{|c|c|c|c|c|c|}
\hline \multirow[b]{2}{*}{$\begin{array}{l}\text { The readiness of } \\
\text { academics }\end{array}$} & \multirow[t]{2}{*}{ Status } & \multirow[b]{2}{*}{ mean } & Parents & Teachers & Students \\
\hline & & & 4.2385 & 4.5636 & 4.6016 \\
\hline & Parents & 4.2385 & - & $.3252^{* * \pi}$ & $.3631^{* *}$ \\
\hline & Teachers & 4.5636 & - & - & .0379 \\
\hline & Students & 4.6016 & - & - & - \\
\hline \multirow[t]{5}{*}{ Resources } & \multirow[t]{2}{*}{ Status } & & Parents & Students & Teachers \\
\hline & & mean & 4.4631 & 4.6453 & 4.6616 \\
\hline & Parents & 4.4631 & - & $.18222^{*}$ & $.1985^{*}$ \\
\hline & Students & 4.6453 & - & - & .0163 \\
\hline & Teachers & 4.6616 & - & - & - \\
\hline \multirow[t]{5}{*}{ International programs } & Status & \multirow[b]{2}{*}{ Mean } & Teachers & Students & Parents \\
\hline & & & 1.4545 & 1.5484 & 1.6955 \\
\hline & Teachers & 1.4545 & - & .0939 & .2409 \\
\hline & Students & 1.5484 & - & - & $.1474^{*}$ \\
\hline & Parents & 1.6955 & - & - & - \\
\hline
\end{tabular}

Table 7 shows the difference in the means of 3 groups. The asterisk indicates whether it is statistically significant or not. It is observed that the parents group has significant difference, when compared to both teachers and students group at .o1 level in all aspects of academics, resources and international programs.

\section{Discussion on findings}

i. Majority of the respondents are Lao PDR people, who live along the Thai-Lao borders, accounted for 74.2 percent. And the major respondents are parents and other concerned people, students and teachers. Parents and students category undertaken the survey in large numbers and contributed at 40.6 and 33.6 percent, whereas the teachers accounted for least 25.8 percent respectively. Moreover most of the students 57.3 percent, who responded the survey, are at Mathayomsueksa secondary school level and 61.2 percent are willing to work in Thailand, when compared to 33.3 percent willing to work in foreign countries. Only least 5.5 percent prefer to work in Laos.

ii. The overall readiness of educational management reported at moderate level (average at 3.6o), but while considering each aspects, the educational management are ready in terms of academics and resources. But they are not ready to offer international programs at present.

iii. The educational management is highly ready in terms of academics, while considering the each aspect individually; the level of readiness is very high in curriculum or program management \& study planning and student admissions. Whereas the levels of other aspects like arranging class, learning methods and learning outcomes assessment is high respectively.

iv. The educational management is highly ready in terms of resources including the each aspects manpower of teachers, budget for organizing learning activities, teaching tools \& equipment and management. 
v. The educational management is not yet ready in terms of international programs, while considering individual aspects; the readiness level is very low for international program management and low for the aspects (course curriculum or programs organized along with foreign institutions, state of internationalization of education and international labor market support).

vi. The result of T-Test indicates that there is no significant difference among Thais and Lao people towards the readiness of educational management. Whereas when tested with One-Way ANOVA, it is found that the significant difference exists among the category of the respondents i.e. among parents/ concerning people, students and teachers/administrators towards readiness of educational management.

vii. Later the pair wise comparison test indicates where the significant difference lies exactly. And it is found that the parents group has the significant differences, when compared to both teachers and students group in all aspects of readiness of educational management with the statistical significance level at .o1.

\section{Conclusion}

From this study, it is obvious that Bueng Kan province educational management has been developed in all the aspects of academics and resources. They are ready to educate people who live along Thai-Lao border. But even though most of the respondents are Lao people who prefer to work in Thailand and foreign countries, the research study also revealed that the educational managements are not yet ready to offer international programs. The educational institutions can take efforts to manage international programs in order to meet the parents, students and teachers expectations. The educational institutions are strong in the aspects of academics and resources, which implies the parents, teachers and students are satisfied in this. Hence they can focus on the aspects which have larger discrepancy i.e., offering international programs.

\section{Recommendations}

The educational institutions may address the issues of international programs and make them ready to serve people at Thai-Lao border areas, Bueng Kan province. The population at this region is almost 100,000 in approximate, hence they can provide better educational service in terms of internationalization. Further studies can be conducted to compare the readiness of educational management between elementary (Prathomsueksa)-level and high-school (Mathayomsueksa)level to guide educational institutions about the issues to be addressed in near future.

\section{References}

Bureau of International Relations. (2008). The study report on The Readiness of Thai Educational Institutions and Thailand's Policy on Supporting the Country's Development to be as Education Hub among Neighboring Countries. Bangkok: Office of Permanent Secretary, Ministry of Education.

Bureau of International Relations.(2010). Preparations and Direction of Thailand in Education. Toward Opening up of Borderless Learning under the AFTA agreements. Bangkok: Office of Permanent Secretary, Ministry of Education. 
110 A Case Study of Educational Management Readiness in Educating People

Office of the Commission on Basic Education, Ministry of Education. (2007). Guidelines for Authority Decentralization and Educational Management for the Committee of Education and Educational Institutions Zones Office under the Ministerial Law on Rules and Procedures and Methods of Authority Decentralization and Educational Management 2007.Bangkok: Agricultural Cooperatives of Thailand Printing.

Sermsakdi Visalaporn. (2009). The research report entitled State of Educational Management for Students on Border Lands in the border provinces of Thailand connected with Cambodia. Bangkok: Wee.Tee. See. Communications.

Suwannee Kammun. (2002). Liberalization of Education: The Way to a Regional Education Hub. Economics and Social Journal. 39(5), 71-74.

Dr.Tanat Titiworatat is Lecturer, Thai Program, St.Theresa International College, Thailand.

Dr.Vichian Puncreobutr is Lecturer, English Program, St.Theresa International College, Thailand. 